\title{
Strategies to Overcome the Challenges Faced by Weekly Boarders: A Case Study of Selected Day Secondary Schools in Chikankata District in Southern Province, Zambia.
}

\author{
Hamaleka Safely Bomber, Harrison Daka (PhD)*, Fumbani Mpande \\ Department of Educational Administration and Policy Studies, University of Zambia, Lusaka, Zambia
}

*Corresponding Author: Harrison Daka (PhD), Department of Educational Administration and Policy Studies, University of Zambia, Lusaka, Zambia

\begin{abstract}
Weekly boarding school has been one of the initiatives introduced in the education sector to help learners coming from distant places to be able to access education. This study sought to come up with solutions/strategies to the challenges faced by weekly boarders in selected day secondary schools in Chikankata district in southern province, Zambia. This study was anchored on the Ecological System Theory propounded by UrieBronfenbrenner (1979) that holds the view that we encounter different environments throughout our lifespan that may influence our behavior in varying degrees. The study employed a qualitative particularly a case study research design using qualitative method of data collection and analysis. The sample consisted of 42 participants comprising pupils, parents, class teachers, and head teachers from the selected schools. Purposive sampling procedure was employed to select the head teachers, teachers, guidance and counseling teachers and parents. Semi-structured interview guide was used to collect the data. The findings of the study showed that pupils who are on weekly boarding faced challenges of transport fares, finding food, travelling long distances and lack of enough time to study. The findings of the study showed that causes of these challenges were poverty, lack of concern of parents/guardians, lack of intervention of school management, psychological and emotional distress, and inadequate income by most parents to support their children's education. The identified strategies to help address these challenges were: strengthening dialogue between the school management and parents/guardians. The study recommended the solutions to the challenges that pupils are facing are: engaging cooperating partners in addressing the challenges of accommodation; and parents concern through by providing pupils with the necessary school requisites, including paying for their school fees and accommodation.
\end{abstract}

Key words: Weekly boarding, challenges, causes, strategies

\section{INTRODUCTION}

The concept of Boarding schools in Northern Rhodesia, as Zambia was known then, was first started in 1935 by Father Zabdry who was a Jesuit missionary at Chikuni mission (Coombe, 1967). He first established village weekly boarding schools in Monze and Chivuna. According to Chomba (2011), there were a number of children who were taken from the surrounding villages of chiefs Chona, Monze and Ufwenuka to go and stay for a week at these boarding schools and go back home on the weekends. Carmody (1992) reveals that sole aim and purpose of the weekly boarding school was to ensure that local children from distant places had easy access to schools with trained teachers.

With the establishment of these weekly boarding schools in mission schools, the proliferation of these schools across the country became a common phenomenon. As full boarding schools gained dominance, most Indigenous African parents wanted their wards and children to have easy access to primary and secondary education from these schools (Carmody, 1992). Within this scenario, it is common to find weekly boarding services still being offered in some of the Zambian schools today.

\section{DESCRIPTION OF BOARDING AND DAY SCHOOLS}

Mander (2012) indicated that boarding schools in England had existed prior to medieval times in which boys were educated at a monastery to become literate clerics. In the $12^{\text {th }}$ Century, the Pope ordered all Benedictine monasteries such as Westminster, to provide charity schools. When these charity schools started charging fees, many public schools started offering boarding facilities which 
they only provided for termly Boarding. Nowadays, some boarding schools have pupils who are weekly boarders; these encounter a lot of difficulties which in some cases affects their academic performance (Mender, 2012). For instance, many public schools in the Commonwealth of Nations do offer weekly boarding services to pupils who are unable to meet payments to be full time boarders. Weekly boarders normally return home during weekends to collect food, and check on their guardians. The rule in these schools are such that those who are in weekly boarding are allowed free time over the weekend to go home; there are no restrictions over the weekends compared to those who are full time boarders.

\subsection{Statement of the Problem}

Weekly boarding has gained acceptance in a number of areas world over. However, it is not disputable that weekly boarding schools are beset by a number of challenges such as long distance from the pupil's place of residence to the schools. Namalundu, Nansenga and Namembo day secondary schools in Chikankata district of southern province of Zambia offer weekly boarding facilities to the surrounding community. A number of studies have been done in Zambia to establish the problems encountered by weekly boarding scholars and various attempts have been made by the communities and other stakeholders to look into the well-being of pupils. However, there is no empirical study that has been conducted to analyze strategies to the challenges faced by weekly boarders and their impact on academic performance. It is against this background that this study will seek to analyze the strategies to overcome the challenges encountered by pupils who are on weekly boarding at these Secondary Schools and the impact on their academic performance.

\subsection{Challenges of Weekly Boarding Pupils}

Day Secondary school administration, teachers, pupils and the communities surrounding weekly boarding have been investigated in various researches to establish the challenges of weekly boarding at such schools. Kelly (1994) commenting on the re-introduction of weekly boarding fees by the Zambian government in1986, noted that weekly boarding costs in secondary schools were much higher than those in day secondary schools and consumed about one quarter of the funds used at Day secondary School. Beere (1993) in a study on in Mongu weekly boarding found that pupils who are on weekly boarding tend to perform poorly as they struggle to look for food and funds for transport fares to ferry them back home after a week-long of being at school. According to Kasanda (2003) a study on St. Mary's Secondary School in Livingstoneindicatedinadequate funding from the parents of those who were on weekly boarding greatly affected their academic performance.

Studies carried out by Ballantine and Hammack (2008) who researched on weekly boarders in United States secondary schools found out that weekly boarders lacked necessities unlike their counterparts who were full time boarders and that they suffered psychological and emotional distress which was one of the reasons for the underperformance. Another report published by the Smith (2009) in United States of America showed that weekly boarders underperformed but study did not investigate the measures to be done to raise their academic performance, which is the concern of the current study.

Another study was conducted in Songea Municipal Council in Tanzania by Mchelu (2015) involving five day community secondary schools. The study investigated the effect of long commuting on students' academic performance in weekly boarding secondary schools in Tanzania. The study specifically investigated the influence of long commuting on student's tardiness, truancy, school transfer and drop outs and its effects on teaching and learning processes and its relationship to poor academic performance. The study findings showed that long commuting students faced a lot of challenges that affected their academic performance. Factors like tiredness, tardiness, truancy, and unfair treatment, incompletion of class work were reported to affect them a lot academically.

Sendor (1984:1) a study in the United States America reveals that"...the social aspects of life at the school are among the most difficult for many students. Being separated suddenly from families and friends and thrust into an environment that includes many new people comes as a shock; especially during the often-trying years of adolescence." The report written by Mchelu(2015) in Kenya showed that 500 pupils were on weekly boarding on the 3 schools, and 345 pupils were underperforming in their academics. Some had difficulties in finding enough time to study, others had no enough food supplies, which made them grow anxiety as to how they are going to survive. The conditions at home were adding salt to the wound; guardians were not pro-active in helping some of these pupils. Some 
of them simply lacked interest with school and they preferred doing other things like involving themselves in farming.

\subsection{Causes of Challenges Faced by Weekly Boarders}

Several studies have been conducted on the challenges faced by weekly boarder pupils in secondary schools. Ferdinand and Zweig (1963) in a survey of Oxford and Manchester students in London conducted a class survey on family background with the aim of establishing how the weekly boarders related with their parents. It was found that most of them described their relationship as detached or strained stating that they did not have a real home as they were usually left in a gap between home and school. Others described their parents as being glad to have them off their hands into weekly boarding school. Reasons for this attitude were rarely explicitly given, however children tended to be aware of the reasons.

The study further revealed that children in weekly boarding faced a lot of challenges which their parents paid little or no attention. The study also revealed that pupils, especially those who rented outside school missed the evening entertainment. They tended to suffer a lot of psychological and emotional attachment. The above study links well with the present study in that it provides information on the challenges faced by weekly boarders although it does not provide guidance on how to overcome these challenges. Kasanda (2003) agreed with the assertions by Sendor (1984). He however, pointed out that this behavior should be treated with the urgency it deserves stating if not given the attention it deserves may cause further challenges in weekly boarding schools. However, unlike the above studies which focused on the effects of the challenges, this study will focus on the strategies to overcome these challenges in relation to the academic performance of the pupil.

Archbold (1954) argued that though some kind of control was necessary for pupils who were on weekly boarding; this became hard as some pupils who are on weekly boarding tend to leave outside school premises in most cases. Cultural differences have also been outlined by some researchers such as Mbozi (2001) as a bone of contention between pupils, parents and the administration especially in weekly boarding schools run by expatriates. He defined culture relativism as the belief that other people and their ways of doing things can be understood only in terms of the cultural context of those people. The above statement is in line with Adam's (1995) observation on the education policy of the United Kingdom. He stated that in 1800 , the country undertook a deliberate policy of educating Native American youths in the way of the dominant western culture so that the Native Americans could be able to assimilate into western society. Aldamre (2012) had similar experience on cultural differences and noted that most of the communication breakdown and misunderstanding that happened in institutions of learning stem from differences in cultural norms especially in weekly boarding schools where administration and teachers may originate from other countries than that of the students.

\subsection{Measures to Mitigate the Challenges of Weekly Boarders}

A study conducted by Aldamre (2012) in Nigeria which investigated the challenges pupils in weekly boarding schools faced and also found that parental involvement in the education of the weekly boarding pupils was vital, especially with regard to improving their academic performance. Further, the study revealed that in terms of mitigating the accommodation challenges faced in weekly boarding schools, the initiative of both the parents and school through involving the local communities surrounding these schools to build houses and rent out such houses to the pupils at cheaper affordable rental charges, especially those coming from far reaching places, is yet another possible way that could help mitigate some of the challenges the pupils are meeting in relation to their academic performance. Definitely, this initiative is deemed to be viable and can help solve accommodation challenges in such schools. This assertion was also supported by Adamre (2012), who in his study found that offering cheap and reasonably charged accommodation to pupils in weekly boarding school can help reduce the challenges faced as far as accommodation for the pupils is concerned.

From literature, we have seen that there many challenges and causes, there has not been study done in Zambia which comprehensively address such. The present study tried to come up with several strategies which could be employed to mitigate the challenges pupils in weekly boarding secondary schools are facing. 


\section{RESEARCH DESIGN AND METHODOLOGY}

This study employed a case study research design. This design was more appropriate for this study as the data collected both qualitative and quantitative in nature. The reason for choosing a case study design was to solicit for detailed, in-depth information on the challenges and their impact on academic performance of the pupils in weekly boarding with a view of ascertaining strategies to be employed to mitigate these challenges.

The target population of this study was for all head teachers, teachers, guidance and counseling teachers, pupils on weekly boarding and parents with pupils at Namulundu and Nansenga secondary schools in Chikankata district of southern province, Zambia. This case, according to Best and Khan (2006) forms an accessible population that is both convenient for the researcher and is representative of the overall target population. The selection of the population was based on the number of secondary schools offering weekly boarding in the district. The sample consisted of 42 participants comprising 15 Pupils, 15 Parents, 9 Class teachers and 3 Head teachers from the selected schools.

Purposive sampling procedure was employed to select the head teachers, class teachers, and parents. Oliver (2010:110) delineates that 'purposive sampling is a sampling method in which the researcher identifies certain participants as being potentially able to provide significant data on the research study'. Purposive sampling allows the researcher to target a particular group of potential participants based on their specific characteristics of interest to the researcher, which in this case was weekly boarding secondary schools. This intentional bias is one of the advantages of purposive sampling.

The data for the study was collected through semi-structured interviews. This enhanced the chances of limiting the shortcomings present when only one kind of instrument is used..Data was collected immediately and the proposal was approved after securing clearance from the Research Ethics Committee. In order to gather the needed data from the participants, the researcher first sought permission from the relevant authorities who included among others the District Education Board Secretary (DEBS), and the three head teachers for the schools selected for the study. Further permission was sought from the ethics committee before the actual commencement of data collection.

The qualitative data that was obtained through semi-structured was analyzed thematically using thematic analysis. Thematic analysis entails the coding and categorizing of the gathered data into themes. The themes arising from the data were used to interpret the study findings.

Studies done by Merriam and Tisdell (2015) showed that validity implies the level to which a study truthfully reflects or assesses the precise concept or constructs that the researcher is attempting to measure, whereas reliability, according to Cohen, Manion\& Morrison (2011) is a synonym for dependability, consistency and reliability over time, instruments and groups of participants. In this context, to establish the strategies to overcome the challenges faced by weekly boarders and their impact on academic performance, researcher of the present study ensured that these principles were adhered to.

In order to uphold ethics in research, this study, was approved by the University of Zambia ethical committee. During the study, in respecting persons to be investigated and keeping their confidentiality was addressed. For this purpose, the present study utilized consent forms, while explaining the purpose of the study to the potential participants.

\subsection{Findings}

This section integrates the findings from the questionnaires and interviews.

\subsubsection{Challenges Faced by Weekly Boarders in Day Secondary Schools}

\section{(a) Findings From the Pupils}

Pupils were asked to indicate the challenges they faced as weekly boarders in relation to their academic performance. Most of the pupils indicated that food was one of the major problems they faced, with a frequency of 13, followed by school fees and lack of academic materials with a frequency of 9 each. Psychological and emotional distress and lack of enough time to study were yet among the many challenges pupils in weekly boarders faced with frequency of 7 each.

Pupils were also asked to state other problems they faced as weekly boarders vis-à-vis academic performance. The following were cited as some of the challenges; lack of toilet facilities, lack of standard accommodation, and lack of bedding facilities, lack of electricity in the dormitories. 


\section{(b) Findings from the Teachers}

Class teachers were asked to indicate the challenges that weekly boarders faced in relation to academic performance. Most of the class teachers reported food, travelling long distances, and transport fares as some of the most common challenges that the weekly boarding pupils faced. The least challenge as noted by the teachers was that of lack of concern of parents/guardians in the education of their children with a frequency of distribution of two.

\section{(c) Findings from the Head Teachers}

Interviews with the head teachers revealed the following as presented below. The head teacher from school 'A' had this to say:

Accommodation and feeding of pupils in boarding school is quite challenging. Most of the parents to the pupils in school are unable to provide their children with money for either accommodation of feeding to take them throughout the ter.(Head Teacher)

The head teacher from school 'B' said the following:

I find it difficult to access finances from the parents of the pupils. Most of them are reported to be either peasant farmers or out of employment. These could not afford to give their children school money. Although this being the case, I seldom send the pupils back home to collect the needed fees.This adversely affect their academic performance because as they are away home, their fellow pupils are learning. In other words, they miss lessons(.Head Teacher)

The head teacher from school ' $\mathrm{C}$ ' said:

We do not have enough accommodation in school for the boarders. This makes some pupils to live in rented houses some distance from school. Due to this type of arrangement, pupils at times miss classes because of long distance. In any case by the time they get to school they are already tired and lack concentration. This affects their academic performance.(Head Teacher)

\section{(d) Findings from the Parents/Guardians}

Parents/guardians as custodians of the children were also asked, in separate interviews to state the challenges their children in weekly boarding faced. Parent 'A' said:

I feel that the government is not doing much to help the pupils in boarding schools, especially as regards providing financial help. We cannot afford as we are vulnerable to unemployment. For instance, as a parent I am failing to support my three children at boarding. (Head Teacher)

Parent ' $\mathrm{B}$ ' had this to say:

Pupils who are on weekly boarding tend to perform poorly as they struggle to look for food and funds for transport fares to ferry them back home after a week-long of being at school. I feel that inadequate funding from us the parents of those who were on weekly boarding greatly affected their academic performance.(Parent)

Parent ' $\mathrm{C}$ ' argued in this manner by stating the following:

Weekly boarders seem to perform poorly because they came from very distant places and they had to go back home during weekends to look after their parents and others to get needs and basic essentials to cater for their school (food), thus miss out lessons and do badly.(Parent)

\subsubsection{Causes of Challenges Faced by Weekly Boarders}

In order to find ways to reduce the challenges faced in weekly boarding, it was found necessary to establish the causes of these challenges. The following section highlights the challenges faced by weekly boarders. 


\section{(a) Findings from the Pupils}

Pupils were asked to state the causes of the challenges they faced as weekly boarders in relation to their academic performance. Most of the pupils, with a frequency of 12 reported that travelling was one of the major challenges that they faced. This was followed by lack of intervention of the school management and lack of concern of parents/guardians. Other causes included lack of employment of parents/guardians, lack of resources, lack of school library and lack of research facilities such as internet.

\section{(b) Findings from the Class Teachers}

Teachers with pupils in weekly boarding were required to state what they felt were the causes of the challenges faced by weekly boarders, vis-à-vis academic performance. All the nine (9) class teachers indicated poverty as one of the major problems faced by weekly boarders. This was followed by those who indicated that lack of intervention by the school management.

\section{(c) Findings from the Head Teachers}

Head teachers in the schools that participated in the study were asked to state, in their own views, what they perceived as causes for the challenges faced by pupils in weekly boarding secondary schools, vis-à-vis academic performance. The findings were as outlined below.

At school "A" the head teacher had this to say:

Some parents are unable to provide money for either accommodation or feeding to their children for the week-long in school. As the school is far from the central business, it is also problematic for pupils to access the money as most of the outlets for Airtel, MTN and Zamtel who offer banking services are very far away from the school. I should also mention that due to this problem, pupils who intend to get their money have to miss classes to go and do this aspect. (Head teacher)

The head teacher from school "B" reported the following:

I personally feel that the distance to homes and schools are very far apart. Our school is situated far from the main town. I should say that some parents do send money for their children's upkeep but access to this is problematic because of long distances to cover to collect such monies. We have no school transport, as such making it even more difficult for the pupils to make such movement. (Head Teacher)

The head teacher from school "C" narrated thus:

The major difficult here is that most pupils come from poor families who cannot afford to pay for school fees and accommodation. If donors were to come in and identify the vulnerable pupils, may be this could become a thing of the past.(Head teacher)

\section{(d) Findings from the Parents}

In separate interviews with the parents, one of the parents bemoaned the high school fees and said the following:

We need our children in school but... I fail because I cannot afford to pay for my two children who are in boarding due to lack of employment opportunities. The small resources that come from my small scale farming in many instances, we consume it at home. Thus it become difficult to save even a small amount for school going children, however, we are trying.(Parent)

Another parents said:

Fees are extravagant. We are out of employment. Where does the government think we can get that much they demand. Surely they should know that not all pupils come from the rich. Instead of blaming us, they should instead come to our aid by all means. (Parent)

From the above sentiments it appears that the outcry from most of the parents/guardian is high school fees. It seems to be one of the major factors making parents/guardians fail to support their children in 
school. The implication here is that poverty has been the main cause for the challenges faced by pupils in weekly boarding schools.

\subsubsection{Strategies to Overcome the Challenges Faced by Weekly Boarders}

The study sought from the study participants to state how the challenges faced by pupils in weekly boarding secondary schools could be overcome. Their reactions were as presented below.

\section{(a) Findings from the Pupils}

In reaction to this variable, pupils reported the following. Most of the pupils with frequency of 12 were of the view that the schools should provide them with transport to school and from their respective locations. However, some pupils, with a frequency distribution of 10, felt that the Ministry of General Education should make sure that they visit the schools regularly to see for themselves what the pupils are passing through and thereby provide find solutions to their challenges.

Further, one of the girl pupils had this to say on this issue:

You must help us pay school and accommodation fees. We also require you to construct new dormitories and ablution blocks. These are too old and cannot carter for us all. Further us girls, you must help us with sanitary pads at least once in a week. (Pupil)

Another pupil had this to say

Classes are locked often starting from Friday, therefore no place to study from. We ask that the school administration should increase study time during night from 18.00 hours to 21.00 hours. The current timings are too short.(Pupil)

\section{(b) Findings from the Class Teachers}

Class teachers were of the view that the schools should embark on production units through which pupils will be provided with adequate food. Asked as how this could be achieved, one of the teachers said the following:

I feel this can be done in such a way that pupils get involved during the holidays and the school pays them some form of remuneration in return and at the same time use the same food produced to feed themselves. (Teacher)

Another teacher said: the school management should identify the most vulnerable pupils and look for possible donors to support such children.

\section{(c) Findings from the Head Teachers}

Head teachers as custodians of the pupils while in school were asked if there are any interventions in school to help overcome the challenges faced by pupils in weekly boarding secondary schools. The findings of the study were as outlined below. The head teacher from school "A" said:

I feel parents should have dialogue with us to find a meaningful solution to these challenges. Yes, we can involve some donors, but the presence of the parents is cardinal for the donors to approve our requests (Teacher)

Another head teacher from school "C" echoed his views in the following statement:

I personally feel parents/guardians should show concern by fully involving themselves in the education of their children. They should not leave it to us alone. It is the responsibility of the school and parent/guardians. They should also know that educating their children means security to their future.(Head teacher)

\section{(d) Findings from the Parents}

Interviews with the parents revealed the following as presented below. One of the parents said:

One way of resolving these challenges is for us and management to meet and agree on the school and boarding fees. Because it looks like in many instances these are just imposed on us. We also need to put our input in these matters. They need to consult us(Head teacher) 
Another parent stated the following:

The only way out is to reduce both school and accommodation fees for the weekly boarders. I see no reason to pay the fees when the dormitories and ablution blocks are deplorable state. I feel also that the schools should provide some form of school transport to ferry the pupils back home after a week-long in school (Parent)

\section{DISCUSSION}

\subsection{Challenges Faced by Weekly Boarders in Secondary Schools}

The discussion below highlights the main challenges that weekly boarders are facing in secondary schools with reference to the schools studied. The study findings have shown that availability of enough food for the pupils was found to be one of the major problems that pupils faced. This perhaps comes as no surprise as no child can concentrate on academic work on while the stomach is empty. Pupils spend much time looking for food to feed them during the week. This is because in most cases, food supplies from home finishes even before the end of the week. As such they resort to looking for part time job to earn some money to buy food, especially those from distant places. The implication of this is that pupils lose out on learning resulting in poor academic performance.

Inadequate funding from the parents/guardians was yet another challenge encountered by most pupils in weekly boarding secondary schools. This can be attributed to the fact that most parents are peasant farmers who solely rely on the farm products which in most cases, as peasant farmers only give them small amounts of money for use both at home and supplementing the needs of their children in school which include school fees and accommodation. In some cases, parents were completely out of employment and could not afford to pay for school fees, accommodation, and transport cost to and from school for their children at the end of each week. The above finding is supported by Kelly (1994) who, commented on the re-introduction of weekly boarding fees by the Zambian government in 1986 and noted that weekly boarding costs in secondary schools were much higher in comparison to those in day schools. The high costs of weekly boarding has impacted negatively on access and consequently the academic performance of pupils as most of them had to spend time looking for the needed money to pay for their education. In support of Kelly's (1996) findings, Dale (1993) also argued that most pupils in weekly boarding tend to perform poorly academically as they spend much of time struggling, looking for money for food and transport to ferry them back home after a weeklong in school. This scenario in most instances result in pupils missing classes or completely not attending school at all. It is no wonder that pupils also cited lack of enough time to study as one of the challenges they face in their academic pursuit.

Lack of academic materials also came out strongly in this study with nearly all the participants citing it. It was found that lack of academic materials such as books and access to internet facilities caused a great challenge to pupils in boarding secondary schools. Pupils struggled with a few materials available in the library which was also not adequately stocked. This demotivated their efforts and in the end developed a lack of interest in schooling. In relation to the above finding, Ahmed, Nkechi, Oliver and Danmole (2017). They argue that most pupils who are in weekly boarding at secondary schools had little motivation to work hard at school as they lacked the necessary educational materials to support their efforts. The resultant effect of this is that pupil in such schools tend to perform poorly in academic work.

Accommodation was also singled out in this study as a big challenge to most pupils in weekly boarding secondary schools. This perhaps comes as a non-surprise because the study findings showed that not all pupils are accommodated in school, instead they rented and resided in houses outside school. This scenario makes pupils lose out in terms of evening activities in school. Further, this arrangement makes, especially the girls more vulnerable to sexual abuse by peers and male teachers. This finding is in line with Dale (1969) who postulates that sexual assault and homosexual tendencies are more rampant in full boarding secondary schools and weekly boarding secondary schools, especially those with co-education arrangements. The poor arrangements in accommodation is a source of concern as pupils in fear of abuses, thus losing out on academic work resulting in poor academic performance. It is no surprise that pupils felt that availability of accommodation, especially in school, would make them easily adapt to school life and thereby enhance the chances of improving on their academic performance. 
Another big challenge that weekly boarders in secondary schools are facing as revealed by the present was the issue of covering long distances to and from school. It was noted that most of the pupils travel long distances each week to and from school as most of them are not accommodated in the school dormitories. Engela, Phillips \& Della (2012) in his study also noted that pupils in weekly boarding travel long distances when going to school and going back home. Such pupils, normally, by the time they reach school are already tired and lack concentration in class. It should, however, be noted that a tired mind cannot easily grasp the concepts in class, thereby affecting the academic performance of the pupil.

The study further showed that parents of some pupils could not afford to give their children transport money to and from school resulting in most pupils either walking or cycling to school. Definitely walking or cycling long distances is a big problem. It is no wonder that some pupils in this study called for the school management to come to their aid by way of availing them a school bus that would ferry them from school to their homes and vice versa. This would reduce time taken for pupils to reach school, let alone the fatigue they go through by walking and cycling. In this way, it is believed that this would help in enhancing the academic performance of the pupils in weekly boarding schools.

\subsection{Causes of the Challenges Faced by Weekly Boarders}

There are several causes for the challenges pupils are facing in weekly boarding in secondary schools in relation to their academic performance. Notable among these are poverty, extravagant school fees, lack of intervention by the school management, lack of concern by parents in the education of their children, and psychological and emotional distress.

This study has established that poverty is one of the causes of the challenges faced by pupils in weekly boarding secondary school. Participants included head teachers, class teachers, pupils and parents of pupils in boarding school attested to this fact. However, it should be noted that most of the parents of the pupils in boarding secondary schools are either retired or unemployed rendering them ineffective in as far as supporting their children in school. It was found out from the study findings that most of the parents were peasant farmers who relied on the farm produce. This on its own is a disadvantage as they managed to get small amounts of money from their produce for use for both house consumption and meeting the school requirements for their children. It is no wonder that most of them found it difficult to fully support their children in their education endeavors.

Lack of concern of the parents/guardians was yet another cause revealed in this study. It was established that most parents lack the zeal of committing themselves to the education of their children through failure to pay for their fees and accommodation. Parents simply send their children to this school expecting some assistance from the schools. True, boarding schools are set up as charities, however, it should be noted that they run as businesses entities and cannot afford to pay fees and accommodation expenses for every pupil in schools, even the vulnerable ones. Ferdinand and Zweig (1963) also expressed their concerns through a study which they conducted to find out the reactions of children from weekly boarding had towards the attitude of their parents on education. The study findings conquer with the present study's finding in the most of the pupils described their relationships with their parents/guardians as detached or strained, while others reported their parents as those who were glad to send their children away into weekly boarding as a way of freeing themselves from the burden. Such parents did not pay much attention to the education of their children.

Lack of intervention by the school management was singled out in this study as one of the major causes of the challenges children in boarding secondary school are facing. In school, there are quite a number of instances were bullying is applied on fellow pupils. However, despite reports by pupils on this behaviour, there seem to be no reaction from the school management to curb the situation. This pose a danger to most pupils in weekly boarding as it affects them psychologically and brings about emotional distress. The resulting effects are poor academic performance by the pupils. The above findings relate well with Sendor (1984) who carried out a number of studies and found that bullying occurred even in day secondary schools offering boarding facilities. He argued that apart from beatings, other non-physical forms of bullying exist in secondary schools including boarding schools. 
Kasanda (2003) also agreed with Sendor (1984) by stating that the occurrence of fighting among students is a source of concern which needed to be addressed with the urgency it deserves so as to bring sanity in secondary schools and boarding schools inclusive. Most pupils live in fear of victimisation and waste time contemplating no these issues. These vices as pointed out by Sendor (1984) and Kasanda (2003) have a negative impact on weekly boarders in relation to their academic performance.

\subsection{Strategies to Overcome Challenges}

The present study shows several strategies which could be employed to mitigate the challenges pupils in weekly boarding secondary schools are facing. Among the notable ones are; involvement of cooperating partners such as the civil society organizations in supporting the weekly boarding pupils such as constructing common lodging houses which do not need renting and providing food, holding strong dialogue mechanisms between the school management and the parents with pupils attending such schools, high parental concern towards the education of their children which include both psychological and emotional motivation.

\section{CONCLUSION AND RECOMMENDATION}

From the study findings it can be concluded that pupils in weekly boarding in secondary schools face a number of challenges which include transport fares, finding food, paying school fees, travelling long distances, lack of enough time to study, psychological and emotional distress and underperforming academically. The study also established the causes of as poverty, lack of concern of guardians, lack of intervention of school management, psychological and emotional distress and inadequate income by most parents.

The possible strategies to overcome the challenges faced by weekly boarding pupils were found that dialogue between the school management and parents should always be strengthen in order to identify and find solutions to challenges facing pupils. Cooperating partners like the community should be engaged to address challenges like accommodation. Parents should also show concern to their children regarding the academic performance of their children.

From the above conclusion, the study recommends the following:

a) there should be continuous dialogue between the school management and parents of pupils who are on weekly boarding.

b) the cooperating partners like the community should be engaged as they can help in addressing challenges faced by pupils who are weekly boarders.

c) school management intervene in addressing some of the challenges pupils who are on weekly boarding face e.g. having a maize field and selling them to pupils at reduced amount.

\section{REFERENCES}

[1] Adamre, J. (2012). 'Challenges faced by weekly boarders in Nigerian public run school. MA Dissertation'. Lagos: University of Nigeria.

[2] Adams, D.W. (1995). Education for extinction: American Indians and the boarding school experience. Lawrence: University press.

[3] Ahmed, M.A., Nkechi, E., Oliver, N.E., and Danmole, B.T. (2017).Comparison of Boarding and Day Senior Secondary School Students' Performance in Biology in Owo, Ondo State, Nigeria. Asia Pacific Journal of Education, Arts and Sciences, Vol. 4 No. 3, July 2017.

[4] Archbord, M.E. (1954). Round the Village Schools. London: University Mission press.

[5] Ballantine, J. H. and Hammack, F. M. (2008).Sociology of Education: A systematic Analysis. NewYork: Prentice-Hall.

[6] Beere, J. (1993). History of the Institute. America: Congregation of the Christian Brothers Press.

[7] Best, J.W. and Kahn, J.V. (2008).Research in Education. India: Prentice Hall.

[8] Carmody, B. P. (1992). Concerns and Jesuit Schooling in Zambia. Netherlands: E: J. Brill.

[9] Chomba, G.M. (2011). "Investigating the benefits of St. Edmunds Secondary School from its Transformation from Boarding to a Day School". A dissertation submitted to the University of Zambia in partial fulfillment of the requirements for the award of the degree of Master of Education in Sociology of Education, University of Zambia. 
Strategies to Overcome the Challenges Faced by Weekly Boarders: A Case Study of Selected Day Secondary Schools in Chikankata District in Southern Province, Zambia.

[10] Cohen, L, Manion, L \& Morrison, K. (2011).Research methods in education.(7th Ed). London: Routledge.

[11] Coombe, T. (1967). The Origins of Secondary Education in Zambia Part I. African social. Research. The Journal of the institute for social Research.Vol.3 N05.PP.

[12] Dale, R. (1969). Mixed or Single Sex Schooling. A research study in Pupil Teacher Relationships. London: Routledge and Kegan Paul Ltd.

[13] Engela, M., Phillips, N. \&DellaCava, F. (2012). 'Indigenous children's rights: a sociological perspective on boarding schools and transracial adoption', International Journal of Children's Rights vol. 20, pp. 279299.

[14] Ferdinand, B. and Zweig.A. (1963).The Student in the Age of Anxiety. A Survey of Oxford and Manchester Students. London: Heinemann Educational Books Limited.

[15] Kasanda, S.M. (2003) (Ed.).Learning Achievement at the Middle basic level: Zambia's Assessment Survey Report-2003. Lusaka: M.O.E.

[16] Kelly, M.J. (1994). Below the poverty line in education: A situation analysis of girl child education in Zambia. Lusaka: UNICEF.

[17] Kelly, M.J. and Kanyika J. (2000).Learning Achievements at the middle basic level .Final Report on Zambia's National Assessment Project. Lusaka: M.O.E

[18] Mander, D.J. (2012).The transition experience to boarding school for male Aboriginal secondary school students from regional and remote communities across Western Australia. Edith Cowan University Retrieved from https://ro.ecu.edu.au/theses/52.

[19] Mbozi, E.M. (2008). Classroom Factors that affect the Quality of Education in selected Basic Schools in Livingstone and Kazungula Districts in Southern Province of Zambia: A doctorate Dissertation. Lusaka: University of Zambia.

[20] Mchelu, A. (2015). 'The Effect of Long Commuting on Students' Academic Performance in Day Community Secondary Schools in Tanzania: A Case of Songea Municipal Council'. A Dissertation Submitted in Partial Fulfillment of the Requirements for the Degree of Master of Education in Administration, Planning and Policy Studies of the Open University of Tanzania.

[21] Merriam, S.B. and Tisdell, E.J. (2015). Qualitative Research: A Guide to Design and Implementation. South East United Kingdom. Jossey Publishers.

[22] Oliver, P. (2010). The Student's Guide to Research Ethics. $2^{\text {nd }}$ edition. Berkshire: Open University Press.

[23] Sendor, E. (1984). Residential magnet school attracts North Carolina's best and brightest. The North American School Board Journal, 171(4), 39.

[24] Smith, A. (2009). Indigenous peoples and boarding schools: a comparative study - the United Nations Permanent Forum on Indigenous Issues September 2011. United Nations Permanent Forum on Indigenous Issues, New York, viewed $10^{\text {th }}$ June 2019, <http://www.un.org/esa/socdev/unpfii/document s/E_C_19_2009_crp1.pdf>.

\section{AUTHORS' BIOGRAPHY}

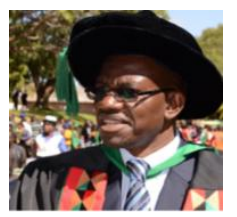

Harrison Daka, is a dedicated academician qualified in Education, Leadership Development, Science education, Medical education, Anthropology, Public Health Programme delivery, Educational Administration and management. Additionally, has had formal training in Leadership training, Curriculum Development, Quality Assurance in learning, HIV programme delivery, Counselling, Strategic Management Planning and strategies of assessment. Has wide-ranging experience in academia, administration, research and consulting for education-sector programmes. He is a professional Counsellor. He is the first Chairperson of Academic Board of Counselors forDiversity Learning Institute of Central Hamburg University of Germany and first and current Chancellor for the same University. He is also a Member of the Board of Governors for Duncan Memorial Trust Bible College. Dr Harrison was also Head of Department for Educational Administration and Policy Studies for 5 years.

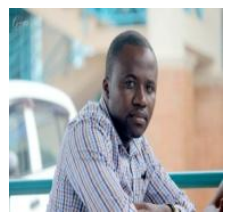

Fumbani, is an Educational Sociologist and an educationist by training. Fumbani has masters in Sociology of Education, Bachelor of Arts with Education, University of Zambia, Diploma in Education from University of Zambia. He has enrolled for PhD in Sociology at Stellenbosch University. He has a nitche in journal publications and presentation papers at international research conferences. Fumbani is a Sociology Lecturer and Head of Department Education and Sociology at University of Africa. Fumbani is a parttime Lecturer at University of Zambia and Diversity Learning Institute, Germany and Kyiv Slavonic 
Strategies to Overcome the Challenges Faced by Weekly Boarders: A Case Study of Selected Day Secondary Schools in Chikankata District in Southern Province, Zambia.

University, Ukraine. He also a part-time Lecturer for Industrial Sociology in Graduate School of Business at University of Zambia.

Citation: Harrison Daka (PhD, et.al). "Strategies to Overcome the Challenges Faced by Weekly Boarders: A Case Study of Selected Day Secondary Schools in Chikankata District in Southern Province, Zambia" International Journal of Humanities Social Sciences and Education (IJHSSE), vol 7, no. 6, 2020, pp. 175-186. doi: http://dx.doi.org/10.20431/2349-0381.0706019.

Copyright: () 2020 Authors. This is an open-access article distributed under the terms of the Creative Commons Attribution License, which permits unrestricted use, distribution, and reproduction in any medium, provided the original author and source are credited. 